\title{
ZWYCZAJE ŻYWIENIOWE UCZENNIC KLAS TRZECICH SZKÓŁ GIMNAZJALNYCH I LICEÓW OGÓLNOKSZTAECACYCH
}

\section{EATING HABITS AMONG FEMALE JUNIOR HIGH THIRD GRADE AND HIGH SCHOOL STUDENTS}

\author{
Ewa Kobos ${ }^{1}$, Anna Kubiak², Barbara Knoff ${ }^{1}$, Józefa Czarnecka ${ }^{3}$ \\ 1 Zakład Pielęgniarstwa Społecznego \\ Warszawski Uniwersytet Medyczny \\ ${ }^{2}$ Wyższa Szkoła Edukacji Zdrowotnej i Nauk Społecznych w Łodzi \\ ${ }^{3}$ Zakład Podstaw Pielęgniarstwa \\ Warszawski Uniwersytet Medyczny
}

DOI: http://dx.doi.org/10.20883/pielpol.2016.14

\section{STRESZCZENIE}

Cel. Cele pracy to poznanie zachowań żywieniowych uczennic klas trzecich szkół gimnazjalnych i ponadgimnazjalnych oraz analiza czynników mających wpływ na te zachowania.

Materiał i metody. W badaniu udział wzięło 121 uczennic w wieku 14-19 lat z 4 losowo wybranych szkół. Uczennice gimnazjum stanowiły $51 \%$ badanej grupy, uczennice liceum $-49 \%$. Z miasta pochodziło $64 \%$ uczennic, ze wsi $-36 \%$. W celu zebrania materiału badawczego zastosowano kwestionariusz ankiety Moje zwyczaje żywieniowe (MZŻ).

Wyniki. Istotnie wyższy odsetek odpowiedzi „tak” w stwierdzeniach „jedzenie wprawia mnie w dobry nastrój” oraz „rzadko stosuję diety" odnotowano w kwestionariuszach wypełnionych przez uczennice liceum ogólnokształcącego w porównaniu z tym odsetkiem z kwestionariuszy uczennic gimnazjum. Niepokój po zbyt obfitym positku czuło $47 \%$ badanych, ze swojej figury niezadowolonych było $69 \%$ uczennic, o swoją wagę martwiło się $53 \%$ badanych, aż $74 \%$ uczennic wolało ważyć mniej niż obecnie. Czasami unikało jedzenia w przypadku odczuwania głodu $35 \%$ uczennic, $57 \%$ po większym positku miało ochotę pozbyć się zbędnych kalorii. W kwestionariuszu MZŻ uzyskano ogółem średnią wartość punktową odpowiedzi na poziomie 11,71 . Najwyższą średnią wartość uzyskano w czynniku „emocjonalne przejadanie się".

Wnioski. Na zachowania żywieniowe uczennic klas trzecich nie mają wpływu ani rodzaj szkoły, do której uczęszczają, ani opinie na temat ich masy ciała wypowiadane przez koleżanki. Więcej zachowań żywieniowych stanowiących ryzyko występowania zaburzeń w odżywianiu wykazują uczennice z miasta oraz będące na diecie odchudzającej.

SŁOWA KLUCZOWE: zachowania żywieniowe, zaburzenia odżywiania, młodzież.

\section{Wprowadzenie}

Żywienie, czyli dobór potraw z odpowiednią zawartością składników pokarmowych, przygotowanych w określony sposób, spożywanych w określonej ilości i liczbie posiłków w ciągu dnia, ma szczególne znaczenie dla wzrostu i rozwoju ludzi w okresie adolescencji. Występowaniu zaburzeń odżywiania w tym

\section{ABSTRACT}

Aim. Acknowledgment of eating habits among female junior high third grade and high school students and analysis of factors which have an impact on these habits.

Material and methods. 121 female students aged 14-19 from 4 randomly chosen schools participated in the research. $51 \%$ of them were junior high students, $49 \%$ - high school students, $64 \%$ lived in cities, $36 \%$ in the country. In order to collect the material a questionnaire 'My eating habits' was used.

Results. More high school students said 'yes' in connection with the following questionnaire points: 'eating makes me happy' and 'I rarely diet'. $47 \%$ felt anxious after a too big meal, $69 \%$ of the students were unsatisfied with their figure, $53 \%$ worried about their weight, $74 \%$ wanted to weigh less than currently. $35 \%$ of the students skipped meals even if feeling hungry, $57 \%$ after a big meal wanted to get rid of the calories. An overall average of 11,71 points was attained in the questionnaire. The highest average was connected with the emotional overeating factor.

Conclusions. The type of school and peer opinion about weight has no impact on eating habits of the third grade female junior high students. Students from cities and being on diets showed more eating habits which showed risks of eating disorders.

KEYWORDS: eating habits, eating disorders, teenagers.

okresie sprzyja wiele czynników: nieadekwatne spostrzeganie obrazu własnego ciała, reklama i łatwy dostęp do niezdrowej żywności, polskie zwyczaje żywieniowe, niewłaściwe zachowania żywieniowe typu: brak spożycia śniadań, niewłaściwa liczba posiłków w ciągu dnia, nadmierne spożycie słodyczy, podjadanie między posiłkami, rozpowszechnienie spożycia posił- 
ków typu „fast food” [1-5], a także brak przedmiotu poświęconego edukacji zdrowotnej, śmieciowe jedzenie w sklepikach szkolnych, styl życia charakteryzujący się małą aktywnością fizyczną [6].

Doniesienia wskazują, że dojrzewanie stanowi jeden z krytycznych okresów występowania otyłości [7, 8]. W Polsce problem ten występuje u około 15-30\% dzieci w okresie dojrzewania [1]. Szacuje się, że 70-80\% młodzieży, u której stwierdzono otyłość w tym okresie życia, będzie też otyłymi w dorosłości [7]. Lansowanie w mediach szczupłej sylwetki jako atrakcyjnej sprzyja sięganiu po restrykcyjne nieprawidłowo zbilansowane diety oraz wystąpieniu zaburzeń odżywiania: bulimii, anoreksji, kompulsywnego objadania się [6]. Rozwój tkanki tłuszczowej u dziewcząt w okresie dojrzewania stanowi niezbędny element tego procesu, a niedobory pokarmowe mogą zaburzać jego naturalny przebieg [9].

Zaburzenia odżywiania klasyfikowane są do grupy zachowań ryzykownych, czyli mających niekorzystny wpływ na zdrowie. Istnieje zatem potrzeba podejmowania działań profilaktycznych i edukacyjnych w tym zakresie. Szkoła jest najlepszym środowiskiem dla planowania i wdrażania edukacji żywieniowej ukierunkowanej również na profilaktykę zaburzeń odżywiania. Pomimo istotnego znaczenia edukacji zdrowotnej ma ona niejednokrotnie niską rangę w środowisku szkolnym, uznawana jest za zadanie dodatkowe, tym samym jest niedoceniana $[10,11]$.

Mając powyższe na uwadze, celami badań były: poznanie zachowań żywieniowych uczennic klas trzecich szkół gimnazjalnych i ponadgimnazjalnych oraz analiza czynników mających wpływ na te zachowania. Przystępując do badań, założono następujące hipotezy badawcze:

1. W badanej grupie uczennic klas trzecich dominują restrykcje dietetyczne.

2. Na zachowania żywieniowe uczennic nie ma wpływu rodzaj szkoły, do której uczęszczają.

3. Uczennice mieszkające w miastach częściej wykazują restrykcje dietetyczne.

4. W grupie uczennic z nadwagą i otyłością dominuje nawykowe i emocjonalne przejadanie się, w grupie uczennic z niedoborem masy ciała dominują restrykcje dietetyczne.

5. Uczennice uprawiające sport wykazują mniej antyzdrowotnych zwyczajów żywieniowych. Uczennice będące na diecie wykazują więcej restrykcji dietetycznych.

6. Uczennice spotykające się z opinią, że są zbyt grube, stosują więcej restrykcji dietetycznych.

\section{Materiał i metody}

Do zebrania materiału badawczego wykorzystano kwestionariusz Moje zwyczaje żywieniowe (MZŻ). Kwestionariusz ten jest wykorzystywany do pomiaru nawyków żywieniowych u osób dorosłych i starszej młodzieży. Może być wykorzystywany w celu diagnozowania zaburzeń w odżywianiu, przewidywaniu skłonności do tycia. Kwestionariusz składa się z 30 twierdzeń, na które badani udzielają odpowiedzi „tak” lub „nie”. Poszczególne twierdzenia kwestionariusza zostały pogrupowane w 3 grupy czynników:

- $\quad$ czynnik 1 - nawykowe przejadanie się, czyli jedzenie na zasadzie nawyku, np. podczas oglądania telewizji,

- $\quad$ czynnik 2-emocjonalne przejadanie się, czyli jedzenie w celu rozładowania emocji,

- czynnik 3 - restrykcje dietetyczne, czyli ograniczanie lub rezygnacja z niektórych pokarmów [12].

Badania zostały zrealizowane w okresie od lutego do marca 2015 r. wśród 121 uczennic klas trzecich na terenie 2 gimnazjów i 2 liceów ogólnokształcących. Kryterium włączenia uczennic do badań było: uczęszczanie do klasy trzeciej szkoły publicznej, pisemna zgoda rodzica uczennic klas trzecich gimnazjum i ustna zgoda uczennic klas trzecich liceum na udział w badaniu. $Z$ badań wyłączono szkoły niepubliczne oraz sportowe.

Do analizy statystycznej wyników wykorzystano program Statistica 10.0. Zgodność rozpatrywanych zmiennych ilościowych z rozkładem normalnym badano przy użyciu testu Shapiro-Wilka. Do porównań międzygrupowych dla poszczególnych skal wykorzystano test U Manna-Whitneya oraz test ANOVA rang Kruskala-Wallisa. Dla zmiennych jakościowych zastosowano test jednorodności chi-kwadrat. Analizę korelacji między wartością BMI a uzyskanymi wynikami przeprowadzono za pomocą współczynnika korelacji rang Spearmana. Za istotne statystycznie uznawano wyniki, gdy wyliczone prawdopodobieństwo testowe $\mathrm{p}$ spełniało nierówność $p<0,05$.

Badaną grupe stanowiły w 51\% uczennice klas trzecich liceum ogólnokształcącego oraz w 49\% uczennice klas trzecich gimnazjum. Z miasta pochodziło 64\% uczennic biorących udział w badaniu, ze wsi - 36\%. W badanej grupie dominowały uczennice w wieku 18 lat $(35 \%)$ oraz 16 lat $(27 \%)$. Średnia wieku uczennic wyniosła 16,9 roku. U 22\% badanych uczennic wykazano szczupłość, niedowagę - u 12\%, nadwagę miało 10\% uczennic, u 2\% występowała otyłość. Systematycznie uprawiało sport w badanej grupie $41 \%$ uczennic, $17 \%$ było na diecie odchudzającej. W badanej grupie tylko $29 \%$ uczennic stwierdziło, że nie spotkało się z opiniami na temat ich masy ciała wypowiadanymi przez koleżanki. Z wygłaszaniem takich opinii zetknęło się $71 \%$ uczen- 
nic, przy czym 21\% z nich usłyszało, że są za chude, 6\% - że są zbyt chude, 7\% - że mają nadmierną masę ciała.

\section{Wyniki}

Analizy wyników wykazały istnienie istotnych statystycznie różnic między udziałami odpowiedzi twierdzących w stwierdzeniu ,jedzenie wprawia mnie w dobry nastrój" $\left(\chi^{2}=9,43 ; d f=1 ; p=0,002\right)$ oraz "rzadko stosuje diety" ( $\left.\chi^{2}=4,6 ; d f=1 ; p=0,032\right)$ w zależności od rodzaju szkoły. Wśród uczennic liceum ogólnokształcącego odsetek odpowiedzi „tak” był wyższy niż wśród uczennic gimnazjum (Tabela 1).

Tabela 1. Różnice istotne statystycznie w stwierdzeniach kwestionariusza MZŻ w zależności od rodzaju szkoły

Table 1. Differences statistically essential in statements from the questionnaire according to the type of school

\begin{tabular}{|c|c|c|c|c|c|c|c|}
\hline \multirow{3}{*}{$\begin{array}{l}\text { Twierdzenie/ } \\
\text { Statement }\end{array}$} & \multirow{3}{*}{$\begin{array}{c}\text { Odpowiedź/ } \\
\text { Answer }\end{array}$} & \multicolumn{4}{|c|}{$\begin{array}{l}\text { Rodzaj szkoły/ } \\
\text { School type }\end{array}$} & \multirow{3}{*}{ df } & \multirow{3}{*}{$p$} \\
\hline & & \multicolumn{2}{|c|}{$\begin{array}{l}\text { Gimnazjum/ } \\
\text { Gymnasium }\end{array}$} & \multicolumn{2}{|c|}{$\begin{array}{l}\text { Liceum/ } \\
\text { High school }\end{array}$} & & \\
\hline & & $\mathrm{N}$ & $\%$ & $\mathrm{~N}$ & $\%$ & & \\
\hline \multirow{3}{*}{$\begin{array}{l}\text { Jedzenie wprawia } \\
\text { mnie w dobry nastrój/ } \\
\text { Eating makes me } \\
\text { happy }\end{array}$} & Tak/Yes & 33 & 53 & 47 & 80 & \multirow{3}{*}{1} & \multirow{3}{*}{0,002} \\
\hline & Nie/No & 29 & 47 & 12 & 20 & & \\
\hline & $\begin{array}{l}\text { Ogółem/ } \\
\text { Total }\end{array}$ & 62 & 51 & 59 & 49 & & \\
\hline \multirow{3}{*}{$\begin{array}{l}\text { Rzadko stosuję diety/ } \\
\text { I rarely diet }\end{array}$} & Tak/Yes & 45 & 73 & 52 & 88 & \multirow{3}{*}{1} & \multirow{3}{*}{0,031} \\
\hline & $\mathrm{Nie} / \mathrm{No}$ & 17 & 27 & 7 & 12 & & \\
\hline & $\begin{array}{l}\text { Ogółem/ } \\
\text { Total }\end{array}$ & 62 & 51 & 59 & 49 & & \\
\hline
\end{tabular}

df - liczba stopni swobody/degrees of freedom,

p-prawdopodobieństwo testowe/probability value

Źródło: opracowanie własne

Source: author's own analysis

W kwestionariuszu MZŻ uzyskano ogółem średnią wartość punktową odpowiedzi na poziomie 11,71. Najwyższą średnią wartość wynoszącą 4,52 uzyskano w czynniku „emocjonalne przejadanie się”. Na zbliżonym poziomie kształtowały się średnie wartości uzyskane w czynnikach: "nawykowe przejadanie się" $(M=3,53)$ oraz „restrykcje dietetyczne” (M = 3,65) (Tabela 2).

Tabela 2. Średnie wartości i odchylenie standardowe poszczególnych czynników kwestionariusza MZŻ

Table 2. Average values and standard deviation of the questionnaire factors

\begin{tabular}{ccccccc}
\hline Czynniki/Factors & M & SD & Med. & Min. & Max. \\
\hline $\begin{array}{c}\text { Nawykowe przejadanie się/ } \\
\text { Habitual overeating }\end{array}$ & 3,53 & 2,69 & 3,00 & 0,00 & 10,00 \\
$\begin{array}{c}\text { Emocjonalne przejadanie się/ } \\
\text { Emotional overeating }\end{array}$ & 4,52 & 2,30 & 5,00 & 0,00 & 9,00 \\
$\begin{array}{c}\text { Restrykcje dietetyczne/ } \\
\text { Dietary restrictions }\end{array}$ & 3,65 & 2,48 & 3,00 & 0,00 & 10,00 \\
Wynik ogółem/Total & 11,71 & 5,35 & 11,00 & 1,00 & 24,00 \\
\hline
\end{tabular}

M - średnia/mean, Med. - mediana/median, SD - odchylenie standardowe/standard deviation, Min. - minimum/minimum, Max. - maksimum/maximum

Źródło: opracowanie własne

Source: author's own analysis
Porównując zachowania żywieniowe w zależności od wybranych zmiennych charakteryzujących badaną grupę, nie wykazano istotnych różnic w wynikach uzyskanych ogółem w kwestionariuszu MZŻ oraz w jego poszczególnych czynnikach w zależności od rodzaju szkoły, do której uczęszczały uczennice $(p \geqslant 0,05)$ (Tabela 3$)$.

Tabela 3. Rodzaj szkoły a zachowania żywieniowe - analiza porównawcza Table 3. School type and eating habits - comparative analysis

\begin{tabular}{|c|c|c|c|c|c|c|}
\hline \multirow[t]{2}{*}{ Czynniki/Factors } & \multicolumn{2}{|c|}{$\begin{array}{l}\text { Gimnazjum/ } \\
\text { Gymnasium }\end{array}$} & \multicolumn{2}{|c|}{$\begin{array}{c}\text { Liceum } \\
\text { Ogólnokształ- } \\
\text { cące/ } \\
\text { High school }\end{array}$} & \multicolumn{2}{|c|}{$\begin{array}{c}\text { Test U Manna- } \\
\text {-Whitneya/ } \\
\text { Mann-Whitney } \\
\text { test }\end{array}$} \\
\hline & M & SD & $M$ & SD & Z & $p$ \\
\hline $\begin{array}{c}\text { Nawykowe przejadanie sięl } \\
\text { Habitual overeating }\end{array}$ & 3,41 & 2,77 & 3,66 & 2,62 & 0,772 & 0,439 \\
\hline $\begin{array}{c}\text { Emocjonalne przejadanie się/ } \\
\text { Emotional overeating }\end{array}$ & 4,22 & 2,40 & 4,84 & 2,17 & 1,599 & 0,109 \\
\hline $\begin{array}{l}\text { Restrykcje dietetyczne/ } \\
\text { Dietary restrictions }\end{array}$ & 3,70 & 2,76 & 3,59 & 2,18 & 0,111 & 0,911 \\
\hline Wynik ogółem/Total & 11,35 & 5,72 & 12,10 & 4,96 & 0,873 & 0,382 \\
\hline
\end{tabular}

$\mathrm{M}$ - średnia/mean, SD - odchylenie standardowe/standard deviation, $Z$ - wartość statystyki testu U Manna-Whitneya dla grup $n>20$ /value of the Mann-Whitney test for groups $n>20, p$ - prawdopodobieństwo testowe/probability value

Źródło: opracowanie własne

Source: author's own analysis

Analiza porównawcza wyników uzyskanych w grupie uczennic pochodzących z miasta i ze wsi wykazała, że wyższe wartości ogółem w skali MZŻ ( $M=13,03$; $p=0,000)$ w czynnikach: "nawykowe przejadanie się" $(\mathrm{M}=4,28 ; \mathrm{p}=0,000)$ oraz ,emocjonalne przejadanie się" ( $M=4,97 ; p=0,006)$ osiągnęły uczennice $z$ miasta (Tabela 4).

Tabela 4. Miejsce zamieszkania a zachowania żywieniowe - analiza porównawcza

Table 4. Place of living and eating habits - comparative analysis

\begin{tabular}{|c|c|c|c|c|c|c|}
\hline \multirow[t]{2}{*}{ Czynniki/Factors } & \multicolumn{2}{|c|}{ Miasto/City } & \multicolumn{2}{|c|}{ Wieś/Country } & \multicolumn{2}{|c|}{$\begin{array}{l}\text { Test U Manna- } \\
\text {-Whitneya/ } \\
\text { Mann-Whitney } \\
\text { test }\end{array}$} \\
\hline & M & SD & M & SD & Z & $\mathrm{p}$ \\
\hline $\begin{array}{c}\text { Nawykowe przejadanie się/ } \\
\text { Habitual overeating }\end{array}$ & 4,18 & 2,73 & 2,40 & 2,23 & $-3,785$ & 0,000 \\
\hline $\begin{array}{l}\text { Emocjonalne przeja- } \\
\text { danie sie//Emotional } \\
\text { overeating }\end{array}$ & 4,97 & 2,36 & 3,75 & 2,00 & $-2,721$ & 0,006 \\
\hline $\begin{array}{c}\text { Restrykcje dietetyczne/ } \\
\text { Dietary restrictions }\end{array}$ & 3,87 & 2,69 & 3,27 & 2,06 & $-1,077$ & 0,281 \\
\hline Wynik ogółem/Total & 13,02 & 5,29 & 9,43 & 4,69 & $-3,515$ & 0,000 \\
\hline
\end{tabular}

$\mathrm{M}$ - średnia/mean, SD - odchylenie standardowe/standard deviation, $Z$ - wartość statystyki testu U Manna-Whitneya dla grup o $n>20$ /value of the Mann-Whitney test for groups $n>20, p-$ prawdopodobieństwo testowe/probability value

Źródło: opracowanie własne

Source: author's own analysis 
Wystąpiły istotne statystycznie różnice między grupami w wynikach czynników: „emocjonalne przejadanie się” oraz „restrykcje dietetyczne” w zależności od wartości BMI (ang. body mass index). W czynniku „emocjonalne przejadanie się" różnica zachodziła między niedowagą/szczupłością a prawidłową masą ciała ( $p=0,008)$, w czynniku „restrykcje dietetyczne” różnica zachodziła między niedowagą/szczupłością a nadwagą/otyłością ( $p=0,038)$. W wyniku ogólnym kwestionariusza MZŻ nie wykazano istotnych różnic w porównywanych grupach (Tabela 5).

Tabela 5. Wartość BMl a zachowania żywieniowe - analiza porównawcza Table 5. BMI value and eating habits - comparative analysis

\begin{tabular}{|c|c|c|c|c|c|c|c|c|}
\hline \multirow[t]{2}{*}{$\begin{array}{l}\text { Czynniki/ } \\
\text { Factors }\end{array}$} & \multicolumn{2}{|c|}{$\begin{array}{c}\text { Prawidłowa } \\
\text { masa ciała/ } \\
\text { Normal } \\
\text { weight }\end{array}$} & \multicolumn{4}{|c|}{$\begin{array}{l}\text { Niedowaga/ Nadwaga/ } \\
\text { szczupłość/ otyłość/ } \\
\text { Underweight/ Overweight/ } \\
\text { thinness obesity }\end{array}$} & \multicolumn{2}{|c|}{$\begin{array}{c}\text { Test } \\
\text { Kruskala- } \\
\text {-Wallisa/ } \\
\text { Kruskal-Wal- } \\
\text { lis test }\end{array}$} \\
\hline & M & SD & M & SD & M & SD & $\mathrm{H}$ & $p$ \\
\hline $\begin{array}{l}\text { Nawykowe przejadanie } \\
\text { się/Habitual overeating }\end{array}$ & 3,52 & 2,66 & 3,87 & 3,02 & 2,66 & 1,54 & 1,1 & 0,565 \\
\hline $\begin{array}{l}\text { Emocjonalne przeja- } \\
\text { danie się/Emotional } \\
\text { overeating }\end{array}$ & 5,00 & 2,12 & 3,60 & 2,16 & 5,00 & 2,77 & 9,9 & 0,007 \\
\hline $\begin{array}{c}\text { Restrykcje dietetyczne/ } \\
\text { Dietary restrictions }\end{array}$ & 3,76 & 2,15 & 2,59 & 2,49 & 5,06 & 3,21 & 7,3 & 0,025 \\
\hline Wynik ogółem/Total & 12,29 & 5,13 & 10,43 & 5,15 & 12,73 & 6,48 & 3,7 & 0,150 \\
\hline
\end{tabular}

$\mathrm{M}$ - średnia/mean, SD - odchylenie standardowe/standard deviation, $\mathrm{H}$ - wartość statystyki testu Kruskala-Wallisa/value of the Kruskal-Wallis test, $\mathrm{p}$ - prawdopodobieństwo testowe/probability value

Źródło: opracowanie własne

Source: author's own analysis

W badanej grupie uczennic najwyższy średni wynik punktów uzyskano w czynniku „restrykcje dietetyczne” $(M=6,60)$, najniższy wynik otrzymano w czynniku kwestionariusza "nawykowe przejadanie się" $(M=3,60)$. Ogółem średnia wyników kwestionariusza wyniosła 15,50 (Tabela 6). Wykazano istotną statystycznie różnicę w porównywanych grupach uczennic ze względu na bycie na diecie w wynikach czynników: „emocjonalne przejadanie się” ( $p=0,047)$, „restrykcje dietetycz$n e "(p=0,000)$ oraz wyniku ogólnym kwestionariusza $(p=0,001)$. Zarówno średnie arytmetyczne, jak i mediany wskazują na to, iż wyższe wartości osiągały dziewczynki będące na diecie odchudzającej.

$\cup$ uczennic systematycznie uprawiających sport najwyższą średnią wartość punktów uzyskano w czynniku „emocjonalne przejadanie się" ( $M=4,12)$, natomiast najniższą wartość średnią w czynniku „nawykowe przejadanie się" $(M=2,49)$. Ogółem w kwestionariuszu średnia wartość punktów wyniosła 10,96. Wykazano istotne statystycznie różnice w wynikach otrzymanych w czynniku „nawykowe przejadanie się”. Wyższe wartości osiągnęły uczennice nieuprawiające systematycznie sportu (Tabela 7).

Tabela 6. Bycie na diecie a zachowania żywieniowe - analiza porównawcza Table 6. Dieting and eating habits - comparative analysis

\begin{tabular}{ccccccccc}
\hline $\begin{array}{c}\text { Czynniki/ } \\
\text { Factors }\end{array}$ & Mak/Yes & \multicolumn{3}{c}{ Nie/No } & SD & M & SD & $\begin{array}{c}\text { Mann-Whitney } \\
\text {-Whitneya/ } \\
\text { test }\end{array}$ \\
\hline $\begin{array}{c}\text { Nawykowe przejadanie się/ } \\
\text { Habitual overeating }\end{array}$ & 3,60 & 2,41 & 3,52 & 2,75 & $-0,366$ & 0,714 \\
$\begin{array}{c}\text { Emocjonalne przejadanie się/ } \\
\text { Emotional overeating }\end{array}$ & 5,40 & 1,95 & 4,35 & 2,33 & $-1,985$ & 0,047 \\
$\begin{array}{c}\text { Restrykcje dietetyczne/ } \\
\text { Dietary restrictions } \\
\text { Wynik ogółem/ } \\
\text { Total }\end{array}$ & 6,60 & 2,08 & 3,06 & 2,12 & $-5,296$ & 0,000 \\
\hline & 15,50 & 5,37 & 10,95 & 5,03 & $-3,265$ & 0,001 \\
\hline
\end{tabular}

$\mathrm{M}$ - średnia/mean, SD - odchylenie standardowe/standard deviation, $Z$ - wartość statystyki testu U Manna-Whitneya dla grup $n>20$ /value of the Mann-Whitney test for groups $n>20, p$ - prawdopodobieństwo testowe/probability value

Źródło: opracowanie własne

Source: author's own analysis

Tabela 7. Systematyczne uprawianie sportu a zachowania żywieniowe - analiza porównawcza

Table 7. Doing sports regularly and eating habits - comparative analysis

\begin{tabular}{|c|c|c|c|c|c|c|}
\hline \multirow[t]{2}{*}{ Czynniki/Factors } & Tak/ & YYes & $\mathrm{Nie} / \mathrm{l}$ & /No & \multicolumn{2}{|c|}{$\begin{array}{c}\text { Test U Manna- } \\
\text {-Whitneya/ } \\
\text { Mann-Whitney } \\
\text { test } \\
\text { M }\end{array}$} \\
\hline & & & & & Z & $p$ \\
\hline $\begin{array}{l}\text { Nawykowe przejadanie się/ } \\
\text { Habitual overeating }\end{array}$ & 2,94 & 2,55 & 3,95 & 2,73 & 2,281 & 0,002 \\
\hline $\begin{array}{c}\text { Emocjonalne przejadanie się/ } \\
\text { Emotional overeating }\end{array}$ & 4,12 & 2,20 & 4,81 & 2,35 & 1,510 & 0,130 \\
\hline $\begin{array}{l}\text { Restrykcje dietetyczne/ } \\
\text { Dietary restrictions }\end{array}$ & 3,90 & 2,78 & 3,47 & 2,26 & $-0,768$ & 0,442 \\
\hline Wynik ogółem/Total & 10,96 & 5,83 & 12,25 & 4,96 & 1,148 & 0,156 \\
\hline
\end{tabular}

$\mathrm{M}$ - średnia/mean, SD - odchylenie standardowe/standard deviation, $Z$ - wartość statystyki testu U Manna-Whitneya dla grup $n>20 / v a l u e$ of the Mann-Whitney test for groups $n>20, p$ - prawdopodobieństwo testowe/probability value

Źródło: opracowanie własne

Source: author's own analysis

Nie wykazano istotnych statystycznie różnic w wynikach kwestionariusza MZŻ w zależności od wyrażania bądź niewyrażania opinii na temat masy ciała uczennic przez ich koleżanki. Wartości średnie uzyskane w poszczególnych czynnikach kwestionariusza kształtowały się na zbliżonym poziomie. Najwyższy średni wynik ogółem $(M=13,75)$ uzyskano wśród uczennic, które spotkały się z opinią na temat zbyt dużej masy ciała (Tabela 8). 
Tabela 8. Opinia koleżanek dotycząca masy ciała badanych a zachowania żywieniowe - analiza porównawcza

Table 8. Peer opinion about the participants' weight and eating habits - comparative analysis

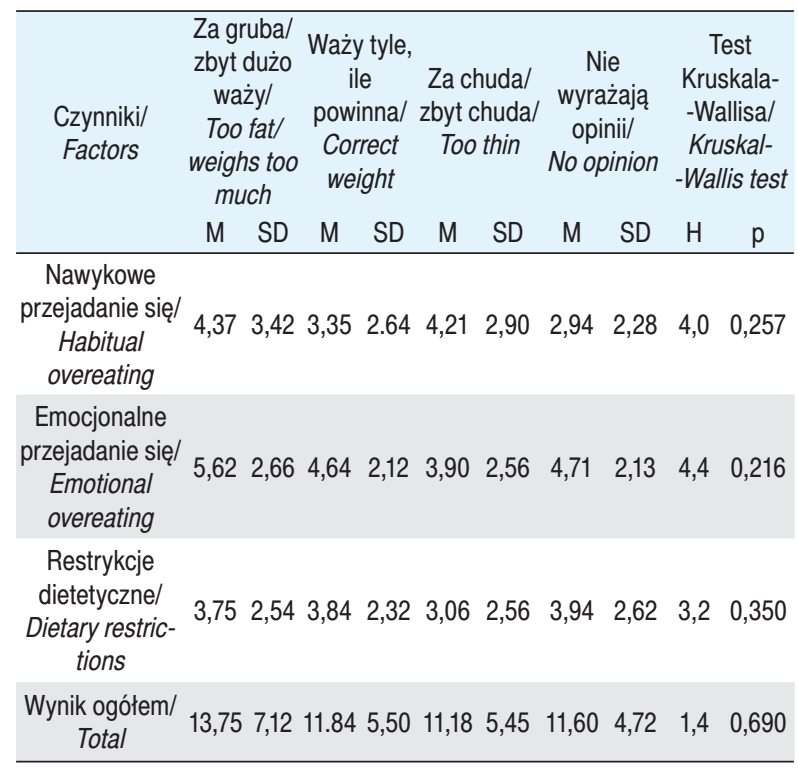

M - średnia/mean, SD - odchylenie standardowe/standard deviation, $\mathrm{H}$ - wartość statystyki testu Kruskala-Wallisa/value of the Kruskal-Wallis test, $\mathrm{p}$ - prawdopodobieństwo testowe/probability value

Źródło: opracowanie własne

Source: author's own analysis

\section{Dyskusja}

Badania nie pokazują, że częstotliwość występowania zaburzeń odżywiania w grupie dziewcząt w krajach Europy ma tendencję wzrostową. Na anoreksję zapadają dziewczęta między 12. a 19. rokiem życia, a dolna granica wieku ulega obniżeniu. Szacuje się, że w Polsce problem ten dotyczy $0,8-1,8 \%$ dziewcząt < 18. r.ż. [1]. W przypadku bulimii zachorowania dotyczą dziewcząt między 15. a 24. rokiem życia. Częstotliwość występowania bulimii u nastolatek waha się w granicach 0,3-7,3\%. Statystycznie często wśród zaburzeń odżywiania u dzieci i młodzieży klasyfikuje się otyłość. Jak wskazują dane, sprzyjają temu m.in. nieprawidłowe zachowania żywieniowe [13].

Celami badań były: poznanie zachowań żywieniowych uczennic klas trzecich szkół gimnazjalnych oraz ponadgimnazjalnych oraz analiza czynników mających wpływ na te zachowania. Pierwszą z hipotez założoną w pracy było przypuszczenie, iż w badanej grupie dominują restrykcje dietetyczne. Narastający problem stosowania diet odchudzających, głodówek, a także ograniczania liczby spożywanych posiłków w grupie dziewcząt wykazali autorzy wielu badań [14-16]. Wyniki badań własnych nie potwierdziły tej hipotezy. W badanej grupie uczennic dominowały zachowania żywieniowe wskazujące na emocjonalne przejada- nie się. K. Nowakowska i wsp. badań z wykorzystaniem kwestionariusza MZŻ (w grupie 14-19-letnich dziewcząt) wykazali na zbliżonym poziomie średnią częstotliwość zachowań z grupy „restrykcje dietetyczne” i „emocjonalne przejadanie się". Dane literaturowe pokazują, że stany emocjonalne mogą wpływać na spożywanie zarówno niedostatecznej, jak i nadmiernej ilości pokarmów. Emocje negatywne silniej wpływają na zachowania osób stosujących diety, otyłych oraz cierpiących na zaburzenia odżywiania [17]. Badania własne potwierdziły, że u uczennic z nadwagą i otyłością dominują restrykcje dietetyczne i emocjonalne przejadanie się, natomiast u szczupłych - nawykowe przejadanie się. Tym samym obalona została hipoteza, że u uczennic szczupłych i z niedoborem masy ciała dominują restrykcje dietetyczne, natomiast u otyłych i z nadmierną masą ciała nawykowe przejadanie się. Stwierdzono, że stosowanie restrykcji dietetycznych, radykalnych metod obniżania masy ciała oraz zaburzenia emocjonalne zwiększają ryzyko otyłości. Niektóre stany psychiczne, np. poczucie izolacji, niezadowolenie z wyglądu ciała, wstyd z powodu nadwagi oraz odczucia towarzyszące byciu obiektem drwin i żartów, doprowadzają do zaburzeń w odżywianiu, które skutkują nadwagą i otyłością [18]. Pozytywne emocje mogą powodować spożycie obfitszych pokarmów, odczuwanie większej przyjemności z jedzenia [17].

Wyniki badań potwierdziły hipoteze, iż zachowania żywieniowe uczennic nie są uzależnione od rodzaju szkoły, do której uczęszczają. Uczestniczące w badaniu uczennice są w okresie adolescencji, która stawia przed nimi określone zadania rozwojowe. Wśród nich możemy wskazać m.in.: osiągnięcie dojrzałych więzi z rówieśnikami obu płci, akceptację własnego wyglądu i chronienie własnego organizmu [19]. Młodzi niemający wsparcia mogą uciekać się do zbliżonych - bez względu na to, w jakiego rodzaju szkole się uczą - form radzenia sobie z napięciem i frustracją, np. wyniszczać się dietami, uciekać w nałogi. Potęgowane to może być charakterystyczną dla okresu adolescencji sensytywnością, czyli wzmożoną emocjonalnością, nadwrażliwością młodzieży [19].

Analiza materiału badawczego nie potwierdziła również hipotezy o częstszym podejmowaniu restrykcji dietetycznych przez uczennice mieszkające w miastach. W literaturze wskazuje się miejsce zamieszkania jako czynnikmający znaczenie w poziomie spożyciażywności i jego strukturze [20, 21]. Także ograniczona kontrola rodziców nad młodzieżą w środowiskach wiejskich związana z czasochłonnymi dojazdami do szkoły jest wskazywana jako czynnik sprzyjający pojawianiu się zachowań anorektycznych [22]. Wśród determinantów społecznych zachowań żywieniowych wymienia się oddziaływanie na zachowanie człowieka innych osób. Za- 
chowanie młodego człowieka może wynikać z naśladowania innych, może być wymuszane przez inne osoby albo stanowić element dostosowania się do grupy [23]. W czasie dorastania młodzież określa, do jakiej grupy chce przynależeć, zabiega o jej uznanie. Standardy kulturowe dotyczące atrakcyjności fizycznej stawiają przed młodymi wysokie wymagania w stosunku do własnego ciała, a niska i nieadekwatna samoocena może prowadzić do patologii w odżywianiu $[15,16,23]$. W pracy nie potwierdzono hipotezy, że zachowania żywieniowe uczennic różnią się w zależności od opinii na temat ich masy ciała wypowiadanych przez koleżanki. Nie wykazano wyższych wartości w czynniku „restrykcje dietetyczne” wśród uczennic spotykających się z opinią, że są za grube lub zbyt dużo ważą.

W kolejnej hipotezie zakładano, że uczennice uprawiające regularnie sport wykazują mniej zachowań antyzdrowotnych w porównaniu z nieuprawiającymi sportu. Obserwacje wskazują, że problem braku satysfakcji z wyglądu ciała narasta wraz z niedostateczną ilością wysiłku fizycznego oraz wzrostem liczby nastolatków z otyłością i nadwagą. Brak satysfakcji z wyglądu staje się przyczyną emocjonalnych i społecznych trudności w okresie adolescencji. Powyższym problemom można zapobiegać poprzez aktywność fizyczną. Aktywność fizyczna wpływa korzystnie na postrzeganie własnego ciała, daje poczucie pewności siebie, większe poczucie własnej wartości niezależnie od posiadanej masy ciała, niesie ze sobą również korzyści psychologiczne związane z udziałem w aktywności [24]. Wyniki badań częściowo potwierdziły założoną powyżej hipotezę. Uczennice uprawiające systematycznie sport osiągnęły istotnie niższe wartości tylko w czynniku „nawykowe przejadanie się". Badania A. Wojtyły i wsp. wykazały, że młodzież w Polsce nie ma świadomości, iż aktywność fizyczna korzystnie wpływa na utrzymanie prawidłowej masy ciała, atrakcyjnej sylwetki [24].

Analiza danych potwierdziła, że uczennice będące systematycznie na diecie wykazują wyższe wartości w czynniku „restrykcje dietetyczne” oraz w ogólnym wyniku kwestionariusza. Wśród powszechnie stosowanych przez nastolatki diet dominują: głodówki, odgraniczenie ilości pożywienia, ograniczenie słodyczy, diety owocowo-warzywne, ograniczenie liczby posiłków [25].

Przystępując do badań, założono, że prezentowane przez uczennice zachowania żywieniowe stanowią czynnik ryzyka wystąpienia zaburzeń odżywiania. W badanej grupie występują nieprawidłowe zachowania żywieniowe predysponujące do rozwoju zaburzeń odżywiania: stosowanie diet odchudzających, świadome ograniczanie się w jedzeniu, poczucie niepokoju po zjedzeniu zbyt obfitego posiłku, niezadowolenie z figury, unikanie jedzenia podczas odczuwania głodu, przypisywanie wadze zbyt dużego znaczenia, obfitsze posiłki spożywane przy zaniepokojeniu, uzależnienie spożycia posiłku od nastroju.

Przedstawione w pracy wyniki badań wskazują na potrzebę wdrożenia działań profilaktycznych w środowisku szkolnym ukierunkowanych na zmianę zachowań żywieniowych uczennic oraz kształtowanie umiejętności życiowych. Podejmowanie wobec dzieci i młodzieży działań profilaktycznych w celu wyeliminowania antyzdrowotnych zachowań żywieniowych jest ważne ze względu na ich negatywne konsekwencje, które w tych grupach wiekowych występują szybciej i są znacznie poważniejsze niż u dorosłych. Wynika to z trwającego jeszcze rozwoju obejmującego biologiczny, emocjonalny, społeczny i intelektualny wymiar.

Profilaktyka zaburzeń odżywiania powinna zmierzać do ograniczania czynników ryzyka oraz obejmować działania wzmacniające pozytywne zasoby osobiste oraz środowiskowe [26]. W literaturze wyodrębnia się trzy stopnie profilaktyki zaburzeń odżywiania. Pierwszy stopień ukierunkowany jest na dzieci i młodzież, które nie są jeszcze zagrożone przyjęciem niewłaściwych zachowań żywieniowych oraz nieodpowiedniego podejścia do własnego ciała; obejmuje np. wszystkich uczniów w klasie. Drugi stopień profilaktyki obejmuje dzieci i młodzież, które są zagrożone przyjęciem takich zachowań; skierowana jest np. na osoby w okresie dojrzewania, pochodzące z rodzin dysfunkcyjnych, wykazujące niektóre symptomy zaburzeń odżywiania. Profilaktyka trzeciego stopnia adresowana jest do osób, u których rozpoznano zaburzenia odżywiania i które były poddane leczeniu. Na żadnym z trzech poziomów nie należy pomijać rodziców - odgrywają oni dużą rolę w kształtowaniu stosunku młodego człowieka do zachowań żywieniowych i własnego ciała [26]. Nawiązanie przez nauczycieli i pielęgniarki współpracy z rodzicami jest ważne z punktu widzenia profilaktyki zaburzeń odżywiania.

Według M. Kowalczuk profilaktyka zaburzeń odżywiania w szkołach powinna uwzględniać: rozwijanie krytycyzmu wobec lansowanego w mediach modelu szczupłej sylwetki, kształtowanie pozytywnego obrazu ciała, ukazanie konsekwencji niewłaściwych metod kontroli masy ciała, podnoszenie samooceny, popularyzowanie zdrowego odżywiania, przekazanie wiedzy na temat zaburzeń odżywiania, sposobów leczenia i udzielania pomocy osobom mającym zaburzenia odżywiania [27].

\section{Podsumowanie}

W badanej grupie uczennic emocjonalne przejadanie się jest dominującym spośród zachowań żywieniowych. Ogółem w skali kwestionariusza wyższe wyniki osiągnęły uczennice z miasta. Zachowania charaktery- 
styczne dla emocjonalnego przejadania się występowały częściej w grupie uczennic z prawidłową masą ciała niż u tych, które były szczupłe lub miały niedowagę. Restrykcje dietetyczne wykazywały częściej uczennice z nadwagą/otyłością niż uczennice z niedowagą lub szczupłością. Uczennice będące systematycznie na diecie wykazały wyższe wartości ogółem w kwestionariuszu oraz w czynnikach: „restrykcje dietetyczne” i „emocjonalne przejadanie się”. Uczennice nieuprawiające systematycznie sportu osiągnęły wyższe wartości w czynniku „nawykowe przejadanie się". Na zachowania żywieniowe uczennic nie mają wpływu ani rodzaj szkoły, do której uczęszczają, ani opinie na temat ich masy ciała wypowiadane przez koleżanki.

\section{Piśmiennictwo}

1. Wojtyła A, Kapka-Skrzypczak L, Paprzycki P, Diatczyk J, Bylina J. Zachowania zdrowotne młodzieży. Raport. Lublin: Instytut Medycyny Wsi; 2011. 33-36.

2. Wołowski T, Jankowska M. Wybrane aspekty zachowań zdrowotnych młodzieży gimnazjalnej - cz. I. Zachowania młodzieży związane z odżywianiem. Probl Hig Epidemiol. 2007; 88 (1): 64-68.

3. Dzielska A, Kołoło H, Mazur J. Zachowania zdrowotne młodzieży związane z odżywianiem w kontekście czynników społeczno-ekonomicznych - kierunek zmian w latach 2002-2006. Probl Hig Epidemiol. 2008; 89 (2): 22-229.

4. Ziółkowska A, Gajewska M, Szostak-Węgierek D. Zachowania żywieniowe młodzieży gimnazjalnej z Warszawy i miejscowości podwarszawskich. Probl Hig Epidemiol. 2010; 91 (4): 606-610.

5. Czarnecka-Skubina E, Namysław I. Wybrane elementy zachowań żywieniowych uczniów szkół średnich. Zywn-Nauk Technol Ja. 2008; 6 (61): 129-143.

6. Ponczek D, Olszowy I. Styl życia młodzieży i jego wpływ na zdrowie. Probl Hig Epidemiol. 2012; 93 (2): 260-268.

7. Przybylska D, Kurowska M, Przybylski M. Otyłość i nadwaga w populacji rozwojowej. Hygeia Public Health. 2012; 47 (1): 28-35.

8. Klump KL. Puberty as a critical risk period for eating disorders: A review of human and animal studies. Horm Behav. 2013; 64 (2): 399-410.

9. Wycisk J, Ziółkowska B. Zaburzenia odżywiania. W: Wycisk J, Ziółkowska B (red.). Młodzież przeciwko sobie. Warszawa: Difin; 2009. 51-88.

10. Woynarowska B. Czynniki warunkujące zdrowie i dbałość o zdrowie. W: Woynarowska B (red.). Edukacja zdrowotna. Warszawa: PWN; 2008. 44-74.

11. Marcysiak M, Zakrzewska M, Zagroba M, Marcysiak M, Ostrowska B, Wiśniewska E, Skotnicka-Klonowicz G. Rola pielęgniarki szkolnej w promowaniu zdrowego stylu życia w ocenie uczniów. Probl Piel. 2010; 18 (2): 184-190.

12. Ogińska-Bulik N, Putyński L. Kwestionariusz „Moje zwyczaje żywieniowe" - konstrukcja i właściwości psychometryczne. Acta Universitatis Lodzensis. Folia Psychologica. 2004; 4: 25-33.
13. Majda A, Barszczyk K. Rola mediów w powstawaniu zaburzeń odżywiania u młodzieży w wieku dojrzewania. Probl Piel. 2012; 20 (1): 34-42.

14. Tomaszewska I, Babicz-Zielińska E, Tomaszewski D. Odmienne postrzeganie własnych sylwetek przez młodzież a ryzyko występowania zaburzeń w odżywianiu. Probl Hig Epidemiol. 2012; 93 (4): 812-816.

15. Malara B, Jośko J, Kasperczyk J, Kamecka-Krupa J. Rozpowszechnienie zaburzeń odżywiania wśród młodzieży w wybranych miastach województwa śląskiego. Probl Hig Epidemiol. 2010; 91 (3): 388-392.

16. Pilska M, Jeżewska-Zychowicz M. Psychologia żywienia. Warszawa: Wydawnictwo SGGW; 2008. 43-49.

17. Campbell A, Hausenblas HA. Effects of exercise interventions on body image a meta-analysis. J Health Psychol. 2009; 14 (6): 780-793.

18. Ponczek D, Olszowy I. Styl życia młodzieży i jego wpływ na zdrowie. Probl Hig Epidemiol. 2012; 93 (2): 260-268.

19. Jeżewska-Zychowicz M. Zachowania żywieniowe i ich uwarunkowania. Warszawa: Wydawnictwo SGGW; 2007. 81-121.

20. Raport GUS, http://www.stat.gov.pl/gus (data dostępu: 20.05.15).

21. Kołłątaj B, Kołłątaj W, Karwat I. Problem zachowań anorektycznych wśród młodzieży gimnazjalnej i licealnej Lublina. Probl Hig Epidemiol. 2010; 91 (3): 393-399.

22. Jeżewska-Zychowicz M. Zmiana zachowań żywieniowych a profilaktyka zdrowotna. Warszawa: Wydawnictwo SGGW; 2011. 39-48.

23. Wojtyła A, Biliński P, Bojar I, Wojtyła C. Zaburzenia odżywiania u polskich gimnazjalistów. Probl Hig Epidemiol. 2011; 92 (2): 343-350.

24. Goluch-Koniuszy Z, Fugiel J. Ocena sposobu żywienia i stanu odżywienia dziewcząt będących w okresie adolescencji, w tym stosujących diety odchudzające. Rocznik PZH. 2009; 60 (3): 251-259.

25. Mroczkowska D, Ziółkowska B, Cwojdzińska A. Zaburzenia odżywiania. Poradnik dla rodziców i bliskich. Warszawa: Scholar; 2007. 101-102.

26. Kowalczuk M. Pedagogiczna diagnoza i profilaktyka zaburzeń odżywiania się u młodzieży szkolnej. Kraków: Impuls; 2008. 84.

Artykuł przyjęty do redakcji: 27.11.2015

Artykuł przyjęty do publikacj: 15.12.2015

Źródło finansowania: Praca nie jest finansowana z żadnego źródła. Konflikt interesów: Autorzy deklarują brak konfliktu interesów.

\author{
Adres do korespondencji: \\ Ewa Kobos \\ ul. Erazma Ciołka 27 \\ 01-445 Warszawa \\ tel.: 228773597 \\ e-mail: kobewa@interia.pl \\ Zakład Pielęgniarstwa Społecznego \\ Warszawski Uniwersytet Medyczny
}

